\author{
Ks. Jerzy Jurkiewicz*
}

UJPII w Krakowie Wydziat Teologiczny Sekcja w Tarnowie

\title{
PRZYGOTOWANIE DO KAPLAŃSTWA W PIERWSZYCH WIEKACH CHRZEŚCIJAŃSTWA
}

\author{
Stowa klucze: \\ kapłaństwo, formacja, świętość, dobra materialne, celibat \\ Treść: \\ I. Różne formy przygotowania do kapłaństwa \\ II. Formacja intelektualna \\ III. Formacja duchowa
}

Rok Kapłański ogłoszony przez Benedykta XVI 19 czerwca 2009 roku stał się na nowo inspiracją do refleksji nad kapłaństwem ustanowionym przez Jezusa Chrystusa. Podsumowując ten rok ks. Vittorio Formenti, szef watykańskiego Centralnego Urzędu Statystyki Kościoła przy Sekretariacie Stanu, zwrócił uwagę, że ostatnie dziesięciolecie charakteryzuje się wzrostem liczby kapłanów, zarówno diecezjalnych, jak i zakonnych. 17 czerwca 2012 roku w Bari na międzynarodowym spotkaniu stowarzyszenia wspierającego powołania kapłańskie, Serra International, podkreślił, że przekaz medialny podkreślający kryzys powołań nie ma pokrycia $\mathrm{w}$ danych statystycznych, jakimi dysponuje Kościół. Zwrócił uwagę, że w latach 2000-2010 liczba duchownych wzrosła z 405 tys. do 413 tys. Do uczestników spotkania w Bari zwrócił się również Benedykt XVI. Przypomniał, że to Bóg jest wychowawcą do życia dobrego i pełnego ${ }^{1}$.

Bardzo ważnym momentem w drodze ku kapłaństwu jest czas formacji. W związku z tym w niniejszym artykule przedstawiono przygotowanie kandydatów do kapłaństwa w pierwszych wiekach chrześcijaństwa. Na podstawie wybranych autorów ukazano różne formy tego przygotowania i zwrócono uwagę na intelektualno-ascetyczny wymiar tej formacji.

\footnotetext{
${ }^{*}$ Ks. Jerzy Jurkiewicz, dr teologii, wykładowca historii Kościoła, patrologii i języków klasycznych na Wydziale Teologicznym Sekcja w Tarnowie UPJPII w Krakowie.

1 „Biuletyn KAI” 18.06.2012.
} 


\section{RÓŻNE RORMY PRZYGOTOWANIA DO KAPŁAŃSTWA}

Kościół pierwszych wieków przejął w tej dziedzinie doświadczenia klasyczne, greckie i żydowskie oparte na układzie mistrz i uczniowie ${ }^{2}$.

Chrystus, zakładając swój Kościół, gromadził wokół siebie wybranych uczniów i konsekwentnie przebywając razem z nimi, przygotowywał ich do głoszenia Dobrej Nowiny. Oni byli naocznymi świadkami i uczestnikami zarówno Jego nauczania, codziennego życia, cierpienia, a także zmartwychwstania. Dlatego czymś naturalnym wydaje się, że św. Paweł, rozpoczynając swoją działalność misyjną, zabrał ze sobą najpierw Tymoteusza, a potem innych współpracowników, chętnych poświęcić się głoszeniu Ewangelii (por. Dz 11,25; Ga 17-18). Taki sposób przygotowania do kapłaństwa polegał na równoległym uczeniu się i podejmowaniu odpowiednich do możliwości kandydata zadań nauczycielskich i pasterskich. Takie przygotowanie nie było ściśle określone liczbą lat, bo praktycznie trwało całe życie jako rodzaj formatio permanens ${ }^{3}$.

W III wieku w Afryce rzymskiej spotykamy bardzo dobrze udokumentowany w źródłach ośrodek kartagiński, utworzony przez duchownych skupionych wokół osoby św. Cypriana. Podobnie jak Paweł Apostoł otrzymał on solidne świeckie wykształcenie w zakresie dialektyki i retoryki. Dlatego też, kiedy został powołany na urząd biskupi w Kartaginie, zmuszony był samodzielnie oddać się studium teologicznemu. Tego również wymagał od swoich duchownych, starając się zachęcić ich do nauki i wewnętrznej formacji. Do grona duchowieństwa dopuszczał kandydatów wybieranych spośród wiernych świeckich, po dokładnym rozważeniu każdej kandydatury ${ }^{4}$.

Przygotowanie do kapłaństwa trwało praktycznie całe życie, a do wyższych święceń dopuszczani byli tylko nieliczni wybrani ${ }^{5}$. Wolność, która przyszła dla Kościoła wraz z Edyktem Mediolańskim w 313 roku, nie wniosła początkowo żadnych istotnych zmian $\mathrm{w}$ proces przygotowania do kapłaństwa $^{6}$. Humanistyczne wykształcenie, a zwłaszcza filozoficzne, przyszli kandydaci zdobywali $\mathrm{w}$ ramach świeckich studiów. Wezwanie do funkcji duchownych oznaczało więc najpierw konieczność uzupełnienia wiedzy teologicznej pod kierunkiem jakiegoś uczonego biskupa czy też poprzez prywatne studium. Nie wszyscy powołani odnajdywali się w nowej rzeczywistości i wielu z różnych powodów już na początku rezygnowało z takiej drogi formacji .

${ }^{2}$ Por. J. Śrutwa, Przygotowanie do kapłaństwa $w$ Afryce Rzymskiej na podstawie pism św. Augustyna, „Vox Patrum” 13-15(1993-1995), z. 24-29, s. 267.

${ }^{3}$ Por. tamże, s. 268.

${ }^{4}$ Por. tamże.

${ }^{5}$ Por. V. Saxer, Vie liturgique et quotidienne a Carthage vers le milieu du III' siecle, Città del Vaticano 1969, s. 72nn.

${ }^{6}$ Hieronim, List 52, 4, PL 22,530-531; wydanie pol.: tenże, Listy, I, Warszawa 1952, tłum. J. Czuj, s. 334.

${ }^{7}$ Por. J. Śrutwa, Przygotowanie do kapłaństwa...dz. cyt., s. 268-269. 
Formacja do kapłaństwa przybierała $\mathrm{z}$ czasem zinstytucjonalizowane formy. Jedną z nich stanowiły wspólnoty klasztorne. Taką formację przeszło wielu znaczących duchownych V i VI wieku. Wartość tego typu formacji dostrzegał Cezary z Arles, twierdząc, że to środowisko „dostarcza wszystkim prowincjom wspaniałych kapłanów".

Drugą instytucją przygotowującą do kapłaństwa były „wspólnoty” istniejące przy biskupach. Należeli do nich młodzi ludzie przygotowujący się do stanu duchownego, a także duchowni z otoczenia biskupa. Grupę tę kształtowała przede wszystkim osobowość biskupa, który wpływał też na styl życia grupy. We wspólnocie, która istniała przy biskupie Cezarym istotnymi elementami były wspólna modlitwa, czytania (zwłaszcza przy posiłkach) oraz dyskusje sprowadzające się często do biskupiego nauczania ${ }^{10}$. Nie była to jednak formacja obowiązująca ani powszechna. Jej zaletą był kontakt z czynnym duszpasterstwem, co dla przyszłych duszpasterzy było sprawą ważna.

Trzecią instytucję przygotowującą do kapłaństwa powołał Synod w Vasense (Vaison) z 529 roku. Zobowiązywał on prezbiterów do kształcenia młodzieńców, którzy mieli przygotować się do posługi w Kościele; prezbiterzy mieli jako „dobrzy ojcowie duchowo karmić tych chłopców poprzez psalmy, pobożne czytania (Pismo Święte) i wychowanie w prawie Bożym"11 . Nie ma jednak bliższych informacji, jak długo miała trwać taka formacja ani kiedy się rozpoczynać. Synod tylko zaznacza, że jeżeli któryś z kandydatów dojdzie do wniosku, iż nie może żyć w celibacie, to bez przeszkód powinien opuścić wspólnotę. Inną jeszcze instytucją zalecaną przez synod były ,szkoły proboszczowskie”. Zakładał je w swojej diecezji Cezary z Arles, o czym świadczą jego biografowie ${ }^{12}$.

Te trzy formy kształcenia nie wchodziły w obowiązkowy kanon przygotowania do kapłaństwa. Pobyt w takiej wspólnocie łączył się zapewne z przechodzeniem kolejnych stopni posług i święceń prowadzących do diakonatu i kapłaństwa. Można było jednak wejść do stanu duchownego bez uczestnictwa w którejś z nich. Nie ulega natomiast wątpliwości, że poziom duchowieństwa w dużej mierze był zależny od typu formacji, jaką dany duchowny miał za sobą. Choć formacja ta była rozciagnięta na lata, to mimo

\footnotetext{
${ }^{8}$ Por. G. Colombes, Il monachesimo delle origini, Milano 1984, s. 267.

${ }^{9}$ Cezary z Arles, Sermo 236, 1, CCL 104, 940: ,praestantissimos per omnes provincias erogat sacerdotes".

${ }^{10}$ Por. tenże, Vita Caesarii I 62, ed. G. Morin, w: S. Caesarii Arelatensi opera omnia, t. 2, Maredsous 1942, s. 326.

${ }^{11}$ Concilium Vasense (a. 529), Ed. Mansi 8, Graz 1960, can. 1, 726: „presbyteri... quomodo boni patres spiritaliter nutrientes psalmos parare, divinis lectionibus insistere et in lege Domini erudire contendant".

${ }^{12}$ Por. tamże, II 20.
} 
wszystko jej poziom nie mógł być zbyt wygórowany, mając na uwadze intelektualny poziom duchownych odpowiedzialnych za tę formację ${ }^{13}$.

Szczyty formacji do kapłaństwa osiagnął św. Augustyn. Najpierw zdobył wyższe wykształcenie w naukach humanistycznych. Był genialnym samoukiem w dziedzinie filozofii. Na wzór św. Ambrożego ${ }^{14}$, z rąk którego otrzymał w 387 roku chrzest w Mediolanie, stał się także genialnym samoukiem w dziedzinie katolickiej teologii. To pozwoliło mu bardzo szybko dostrzec i należycie docenić potrzebę permanentnej formacji ludzi, którzy pragnęli wstąpić do stanu duchownego ${ }^{15}$.

Kościół od początku zdawał sobie sprawę z ważności przygotowania do kapłaństwa. W tej sytuacji podejmował różnorodne inicjatywy zmierzające do kształtowania odpowiedniego poziomu intelektualno-ascetycznego kandydatów, którego uwieńczeniem było dopuszczenie do święceń.

\section{FORMACJA INTELEKTUALNA}

Według Orygenesa „przy wyświęceniu na arcykapłana wymagana jest również obecność ludu, po to, aby wszyscy wiedzieli i byli pewni, że na stanowisko kapłańskie zostaje powołany ten, kto wyróżnia się wśród ludu szczególnym dostojeństwem, wykształceniem, świętością i znakomitością w zakresie wszelkich cnót; zostaje powołany na kapłana w obecności ludu, aby potem nikt nie miał żadnych wahan czy wątpliwości" " ${ }^{\prime \prime}$. Odpowiedniej wiedzy, roztropności i życiowej mądrości wymaga od kapłana także św. Jan Chryzostom. Są one mu bardziej potrzebne, niż dobre uczynki i umartwienia: „choćby kto wykazywał nawet wielką pobożność, to i tak nie śmiałbym go jeszcze wybrać, gdyby z pobożnością nie łączył wiedzy"17. Kapłan, jak dalej naucza Złotousty, żyje nie dla siebie, lecz dla drugich, jest ich pasterzem, co wymaga odpowiedniego przygotowania. Niełatwo jest prowadzić ludzi drogą cnoty, trzeba umieć odpowiednio przedstawić im prawdę oraz wpłynąć na ich wolę, aby chcieli iść za dobrem ${ }^{18}$. Potrzebna jest kapłanowi wiedza i roztropność. Gdy pasterz nie będzie potrafił odpowiednio podchodzić do powierzonych swej pieczy, jego praca stanie się bezskuteczna ${ }^{19}$.

${ }^{13}$ Por. A. Żurek, Formacja intelektualno-ascetyczna duchowieństwa w V-VI wieku w Galii na podstawie pism św. Cezarego z Arles, „Vox Patrum” 13-15(1993-1995), z. 24-29, s. 180.

${ }^{14}$ A mbroży, De officiis ministrorum 11, 3-4, PL 16, 27, wydanie pol.: Święty Ambroży z Mediolanu, Obowiqzki duchownych, tłum. K. Abgarowicz, Warszawa 1967, s. 20.

${ }_{15}$ Augustyn, List 21, 3-6, CSEL 34/1, 51-52, wydanie pol.: tenże, Listy, thum. W. Eborowicz, Pelplin 1991, s. 175-176.

${ }^{16}$ Orygenes, In Leviticum hom. 6, 3, PG 12, 469, wydanie pol.: PSP 31, z. 2, thum. S. Kalinkowski, s. 76.

${ }^{17}$ Jan Chryzostom, De sacerdotio III 11, SCh 272, 190, BOK 1, s. 86.

${ }^{18}$ Por. tamże, II 3, SCh 272,112, BOK 1, s. 60.

${ }^{19}$ Por. W. Kania, Godność $i$ wielkość chrześcijańskiego kaptaństwa wg św. Jana Chryzostoma, „Vox Patrum” 13-15(1993-1995), z. 24-29, s. 125-126. 
Nie dość dużo wiemy na temat bezpośredniego przygotowania intelektualnego do kapłaństwa. O stanie tego przygotowania nie powinno świadczyć także przygotowanie wielkich ojców Kościoła. Ich wykształcenie świeckie, uzyskane często $\mathrm{w}$ najlepszych ośrodkach naukowych, nie było bezpośrednim przygotowaniem do kapłaństwa. Niemniej jednak bardzo pomagało w zastosowaniu zdobytej wiedzy i umiejętności w służbie Kościoła. Na Wschodzie istniały szkoły chrześcijańskie w Aleksandrii, Antiochii (Asketerion Diodora), Nisibis i Edessie. Niektóre z nich, odznaczające się wysokim poziomem studiów teologicznych, przygotowywały znakomitych teologów. Gwarantował to program i ustrój niektórych z nich ${ }^{20}$. Nie przygotowywały one jednak bezpośrednio do stanu duchowego, choć wielu absolwentów mogło zajmować kościelne stanowiska. Ważnym czynnikiem była tu jednak formacja intelektualna. Pozwalała kandydatowi do kapłaństwa nadrobić zaległości i przygotować się drogą samokształcenia do wykonywania obowiązków kapłańskich ${ }^{21}$.

Innego typu przygotowanie intelektualne dawały wspólnoty monastyczne. Wydaje się, że oprócz nauki czytania i pisania, pomocnej w lekturze Pisma Świętego, szkoły monastyczne propagowały ideał duchownego, który nawiązywał do myśli św. Pawła: „Bóg wybrał właśnie to, co głupie w oczach świata, aby zawstydzić mędrców" (1 Kor 1,27). W tym duchu, jak się wydaje, należy rozumieć niechęć okazywaną wobec świeckiego wykształcenia $i$ to nawet u ludzi faktycznie wysoko wykształconych. Wyżej ceniono dary duchowe i osobiste zaangażowanie niż wykształcenie ${ }^{22}$.

$\mathrm{Z}$ drugiej strony jednak wielu przedstawicieli życia kościelnego wyrażało przekonanie, że wykształcenie intelektualne jest dla duchownego potrzebne i pożyteczne. Wspominany już Jan Chryzostom był zdania, że nauczanie należy powierzyć wykształconym przedstawicielom duchowieństwa, pozostałym zaś zezwolić tylko na udzielanie sakramentów ${ }^{23}$. W programie tego wykształcenia wysoko ceniono znajomość Pisma Świętego. Dla części zachodniej Statuta ecciesiae antiqua domagały się, żeby kandydat na biskupa przed święceniami osiagnął odpowiedni poziom literackiego wykształcenia, aby mógł wyjaśniać Pismo Święte oraz żeby znał sposoby kościelnego wykładu Biblii ${ }^{24}$.

Odpowiedniej formacji intelektualnej od kapłanów wymagał także Grzegorz Wielki. Kapłan według niego powinien zdobyć wiedzę w takim

${ }^{20}$ Por. R. Nelz, Die theologischen Schulen der morgenländischen Kirchen, Bonn 1916, 59-62, N.W. Pigulewska, Kultura syryjska we wczesnym średniowieczu, thum. Cz. Mazur, Warszawa 1989, s. 101-120.

${ }^{21}$ Por. W. Myszor, Przygotowanie do kapłaństwa w IV i V wieku w kościele wschodnim, „Vox Patrum” 13-15(1993-1995), z. 24-29, s. 263.

${ }^{22}$ Por. H. von Campenhausen, Kirchliches Amt und geistliche Vollmacht in den ersten drei Jahrhunderten, Tübingen 1963, s. 323-332.

${ }^{23}$ Por. Jan Chryzostom, In 1 ad Corinthios hom., 3, 3, PG 61, 26.

${ }^{24}$ Por. W. Myszor, Przygotowanie do kapłaństwa w IV $i$ V wieku w kościele wschodnim, dz. cyt., s. 263-264. 
stopniu, w jakim będzie mu ona potrzebna w prowadzeniu ludzi do Boga. Wiedza kapłana powinna być solidna, ponieważ jak mówił papież, jest ona „okiem” pasterza, które mu służy w prawidłowym kierowaniu wiernych ku ich wiecznemu przeznaczeniu ${ }^{25}$. Kapłan jako nauczyciel ${ }^{26}$ przez swoją wiedzę ma się stawać dla innych ,światłem prawdy”. Powinien on także odznaczać się umiejętnością właściwego „rozróżniania”, dzięki której będzie mógł zachować właściwą ocenę zdarzeń, a także skutecznie odróżniać wady od cnót $\mathrm{t}^{27}$.

Grzegorz zwracał uwagę na umiejętność dokładnego wnikania w problematykę ludzkiego ducha, borykającego się z różnymi trudnościami. Źródłem tej wiedzy jest Pismo Święte oraz przykład życia, jaki pozostawili święci. Wiedza kapłana wtedy jest pełna, gdy towarzyszy jej praktyczna troska o dobro ludzkich dusz. W pierwszym rozdziale Reguty pasterskiej Grzegorz, posługuje się często wyrażeniem peritus. Określa nim kapłana, który zdobył właściwą wiedzę, jaka jest potrzebna do kierowania ludźmi. Stanowczo ostrzega, aby imperitus - 'niedoświadczony' nie ważył się przystapić do święceń. $Z$ tego powodu każdy kandydat przed przyjęciem święceń powinien podjąć żmudny wysiłek poznania samego siebie. Świadomość zależności od Boga, której towarzyszy miłość oraz podejmowanie wysiłku $\mathrm{w}$ celu lepszego poznania samego siebie, stanowi fundament dalszego rozwoju duchowego. Grzegorz Wielki traktuje wiedzę jako przymiot urzędu nauczycielskiego. Jej potrzeba wypływa z natury tego urzędu, gdyż kapłan jest nauczycielem, sędzią, lekarzem, doradcą i przewodnikiem. Motywem studium, którego konieczność papież uzasadnia biblijnie, jest działalność duszpasterska, która ma prowadzić do zbawienia dusz ${ }^{28}$.

\section{FORMACJA DUCHOWA}

Zgodnie z zaczerpniętą z filozofii stoickiej zasadą porządku i zajmowania przez każdego właściwego mu miejsca ${ }^{29}$ biskupi i prezbiterzy jako pasterze ludu powinni być ludźmi duchowymi ${ }^{30}$, ponieważ tacy ludzie powinni kierować ludem ${ }^{31}$.

${ }^{25}$ Por. J.C. Hedley, Lex levitarum, la formation sacerdotale d'apres Saint Gregoire le Grand, Maredsous 1922, s. 163-172.

${ }^{26}$ Por. Grzegorz Wielki, Moralia IX 15. 23, PL 75, 964.

${ }^{27}$ Por. tenże, Epistula I 24, CCL 140. 30; Regula pastoralis I 9, PL 77, 21-22; por. Hedley, Lex levitarum, la formation sacerdotale d'apres Saint Gregoire le Grand, dz. cyt., s. 68.

${ }^{28}$ Por. S. Sojka, Formacja kapłanów wedtug zasad św. Grzegorza Wielkiego, „Vox Patrum"13-15(1993-1995), z. 24-29, s. 207-208.

${ }^{29}$ Por. A. Houssiau-J.P. Monet, Le sacerdoce du Christ et de ses serviteurs selon les Peres de l'Eglise, Louvain 1990, s. 36.

${ }^{30}$ Por. Orygenes, Homilia in Numeros 2,1, PG 12, 590-591, PSP 34, z. 1, s. 38-39; A. Houssiau, J.P. Mondet, Le sacerdoce du Christ et de ses serviteurs selon les Peres de l'Eglise, dz. cyt., s. 8. s. $97-98$

${ }^{31}$ Por. M. Szram, Orygenes o kaptaństwie, „Vox Patrum” 13-15(1993-1995), z. 24-29, 
Duchowość kapłańska według Ambrożego powinna być oparta na podstawowym obowiązku lewity, bycia świętym do czego miał się przygotować. Obowiązek ten wypływał $\mathrm{z}$ faktu wybrania przez Boga ${ }^{32}$. Lewita chrześcijański miał realizować to wezwanie do świętości przez całkowite zawierzenie Bogu, przez praktykowanie cnót i rozważanie Bożego słowa. „Lewici są więc Jego mężami i Jego dostojnikami, którzy nie knują w sercu żadnego podstępu, żadnej nie chowają zdrady, lecz strzegą słów Jego i w sercu rozważają jak rozważała je także Maryja" ${ }^{33}$. W praktyce to życie wiarą, złączone z praktykowaniem cnót, wyrażało się $\mathrm{w}$ odpowiednim odniesieniu chrześcijańskiego lewity do dóbr materialnych i w zachowaniu cnoty czystości.

Lewici Starego Testamentu niczego nie posiadali, jedynym ich bogactwem był Bóg. Podobnie i lewici Nowego Testamentu powinni być wolni od przywiązania do dóbr materialnych: „Nie upatrujemy żadnych korzyści w dostatku i bogactwie, ale uważamy je za szkodliwe, jeśli nie są w pogardzie. Bardziej dolega nam ich ciężar, gdy je posiadamy, aniżeli strata, gdy je rozdajemy"34. Biskup Mediolanu realizował to wezwanie. Rozdając swoje dobra biednym, nie wymagał jednak, aby ci, którzy wstępują na drogę kapłaństwa, pozbywali się wszystkiego: „Błogosławiony jest wprawdzie ten, kto wszystko rozdaje i idzie za Nim, lecz i ten jest błogosławiony, który z serca dzieli się tym, co posiada. Zresztą Pan Bóg nie wymaga, aby rozdać swój majątek, tak jak Elizeusz, który pozabijał swoje woły i nakarmił ubogich tym, co posiadał, aby nie był skrępowany żadnymi domowymi kłopotami, lecz porzuciwszy wszystko udał się na naukę do proroka" ${ }^{, 35}$.

Te słowa Ambrożego świadczą o dyskusji na temat posiadania dóbr materialnych przez duchownych. Prawdopodobnie wpłynął na to rozwijający się w tym czasie monastycyzm, z którego wywodziło się wielu duchownych. Biskup Mediolanu zdawał sobie sprawę z ważności tego zagadnienia. Uważał, że duchowny nie musi wyzbywać się tego, co posiada, jeżeli będzie się dzielił tym z potrzebującymi ${ }^{36}$.

Najważniejszą cnotą spośród wielu, którą miał zachować lewita Nowego Testamentu, była według Ambrożego czystość. Temu zagadnieniu poświęcił wiele miejsca w swych homiliach, zarówno ze względu na toczącą się wówczas dyskusję na ten temat, jak i na orzeczenia synodów dotyczące tej materii. Synody nakazywały zachowanie celibatu tym duchownym, którzy nie wstapili jeszcze $\mathrm{w}$ związki małżeńskie albo zostali wdowcami, a całkowitą wstrzemięźliwość tym, którzy już w takich związkach byli. Echo tych dyskusji odnajdujemy w homiliach Biskupa Mediolanu do duchownych: „Niejednemu wydaje się rzeczą dziwną, dlaczego nawet przed chrztem

${ }^{32}$ Ambroży, De officiis I 50, 251, w: Sancti Ambrosii Episcopi Mediolanensis Opera (dalej: SAEMO) XIII 174-176, PL 16,106.

${ }^{33}$ Tamże, 150,258, SAEMO XIII 180, PL 16,109.

${ }^{34}$ Tamże, 1,9, 28, SAEMO XIII 38, PL 16, 35.

${ }^{35}$ Tamże, I 30, 149, SAEMO XIII 114, PL 16, 72.

${ }^{36}$ Por. tamże, I 30, 152, SAEMO XIII 116, PL 16, 73. 
powtórnie zawarte małżeństwo stanowi przeszkodę, jeśli chodzi o wybór służby kapłańskiej i o pierwszeństwo w otrzymaniu święceń" ${ }^{37}$.

Wprowadzenie obowiązku celibatu i absolutnej wstrzemięźliwości spotkało się ze sprzeciwem tych, którzy byli żonaci. Powoływali się na starotestamentalny zwyczaj, według którego lewita powstrzymywał się od pożycia małżeńskiego na kilka dni przed pełnieniem funkcji kapłańskich. „Wspominam o tym dlatego - mówi Biskup - że często w miejscowościach odległych klerycy, a nawet kapłani, miewali dzieci. To zgorszenie próbują złagodzić powołując się na dawny rzekomo zwyczaj, kiedy odprawiano Mszę św. po dłuższej przerwie" ${ }^{38}$. W odpowiedzi na to Ambroży przypomina starotestamentalny zwyczaj oczyszczenia się ludu, prania swych szat przed przystapieniem do składania ofiary: „Jeśli tak wielka była staranność wtedy, gdy wszystko w kulcie było forma, jak wielka powinna być teraz, gdy naszym udziałem stała się Prawda. Zrozum, kapłanie i lewito, co oznacza pranie twych szat, abyś z czystym ciałem zbliżał się do sprawowania świętej ofiary! Jeżeli ludowi zabronione było przystępowanie do ofiary w niewypranych szatach, to ty z brudnym ciałem i duszą zarazem miałbyś za innych się modlić, śmiałbyś innym posługiwać?"39. Biskup mówi tu o „formie” i o „prawdzie”, o dwóch różnych etapach historii zbawienia. Lewici Nowego Testamentu, ponieważ służą prawdzie, są według Ambrożego zobowiązani do większego praktykowania doskonałości w tej dziedzinie niż lewici Starego Testamentu ${ }^{40}$.

Mówiąc o motywach zarówno praktykowania ubóstwa, jak również zachowania wstrzemięźliwości i celibatu, św. Ambroży odwołuje się do najważniejszego motywu, jakim jest naśladowanie Chrystusa ${ }^{41}$ : „Nikt nie powinien wstydzić się, że szczodrze dając ubogim z bogatego stał się biednym, ponieważ i Chrystus będąc bogatym stał się ubogim, aby wszyscy ubóstwem Jego stali się bogatymi... Dlatego mówi Apostoł: I w tym daję radę, bo to jest pożyteczne dla was, abyście naśladowali Chrystusa (2 Kor 8,10$){ }^{\natural 42}$. Biskup zachęcał także do praktykowania cnót: „Jak człowiekowi cnotliwemu z powodu przykrości wcale nie ubywa szczęścia, tak wcale nie przybywa mu z powodu rozkoszy cielesnych lub korzyści materialnych. Pięknie mówi o tym Apostoł: «To wszystko, co stanowiło dla mnie zysk ze względu na Chrystusa, uznałem za stratę, [...] ze względu na najwyższą cenę znajomości Chrystusa Jezusa» (Flp 3,8),"43.

Godność kapłańska przewyższa godność anielską, dlatego jak twierdzi Jan Chryzostom, również kapłan powinien prowadzić anielskie życie. Trzyma on Ciało Chrystusa, dlatego też czyste powinny być jego ręce, słowa

\footnotetext{
${ }^{37}$ Tamże, I 50, 248, SAEMO XIII 172, PL 16, 104.

${ }^{38}$ Tamże, I 50, 249, SAEMO XIII 174, PL 16, 105.

${ }^{39}$ Tamże, I 50, 249, SAEMO XIII 174, PL 16,105.

${ }^{40}$ Por. K. Gurda, Nauka o kaplaństwie u św. Ambrożego, „Vox Patrum” 13-15(19931995), z. 24-29 s. 115-116.

${ }^{41}$ Por. tamże, s. 114-117.

${ }^{42}$ A mbroży, De officiis I 30, 151, SAEMO XIII 114-116, PL 16, 73.

${ }^{43}$ Tamże, II 4, 12, SAEMO XIII 190, PL 16, 113.
} 
i myśli. „Gdy Ducha Świętego wzywa i najstraszliwszą składa ofiarę, i dotyka Pana całej społeczności, w jakim go rzędzie postawimy, jakiej czystości, jakiej pobożności będziemy się domagać od niego! Pomyśl, jakie winny być ręce, koło takich rzeczy posługujące, jaki język wypowiadający takie słowa, czy nie czystsza dusza tak wielkiego Ducha przyjmująca. Wtedy aniołowie asystują kapłanowi i cały oddział niebieskich Potęg woła i całe miejsce koło ofiarnego ołtarza napełnia się czcią dla Tego, który na ołtarzu spoczywa"44.

Ważnym w życiu kapłana jest także przykład. Oczy wszystkich zwrócone są na kapłana, dlatego powinien się przygotować do bycia wzorem: ma być żywym obrazem, jak trzeba postępować. Za jego przykładem idą wszyscy, patrzą na niego wszyscy jak na wzór i obraz. Zadaniem kapłana jest nauczać, upominać, wzywać do nawrócenia i grozić karami. Aby to mógł czynić, sam musi promieniować świętością życia: „Dusza jego powinna być jaśniejsza od promieni słońca, zewsząd winna lśnić jej piękność, aby mogła rozweselić i równocześnie oświecić dusze patrzących" ${ }^{45}$.

Odpowiedniego poziomu moralnego oraz gorliwości w nauczaniu wymagał od swoich kapłanów także Cezary z Arles. Życie na odpowiednim poziomie moralnym według niego to, inaczej mówiąc, osobista świętość ${ }^{46}$. Wyznaczały ją poszczególne przepisy kościelne, uchwalane zwłaszcza na synodach. Domagały się one, by do święceń dopuszczać ludzi dojrzałych, cieszących się dobrą opinią, stałych w wierze. Wykluczano powtórnie żonatych, publicznych grzeszników i konwertytów ${ }^{47}$. Do wymagań ogólnie znanych Cezary dodawał także te, które uważał za konieczne, np. bezinteresowność i brak przywiązania do dóbr materialnych ${ }^{48}$.

Drugim postulatem, jaki Cezary kierował pod adresem duchownych, było nauczanie, czyli głoszenie kazań. Nikt i pod żadnym pretekstem nie powinien się dyspensować $\mathrm{z}$ tego obowiązku. Wymagania stawiane $\mathrm{w}$ tym względzie nie były zbyt wygórowane. Wystarczyło, aby duchowny przypominał najważniejsze i podstawowe prawdy i zasady, jakie zawarte są w Ewangelii. Na takie nauczanie mógł się zdobyć każdy duchowny: wystarczyła do tego znajomość Ewangelii i prawa kościelnego ${ }^{49}$.

\footnotetext{
${ }^{44}$ Por. Jan Chryzostom, De sacerdotio VI 4, SCh 272, 316, BOK I, 132-133.

${ }^{45}$ Por. W. Kania, Godność $i$ wielkość chrześcijańskiego kaplaństwa wg św. Jana Chryzostoma, dz. cyt., s. 125.

${ }^{46}$ Por. Cezary z Arles, Sermo 1, 19, SCh 175, 266, PSP 52, 31: „Każdy kapłan winien zasłużyć na określenie «święty»".

${ }^{47}$ Por. tamże, 1, 14, SCh 175, 253-254, PSP 52, 27. Są to wymagania powtarzane przez ówczesne synody.

${ }^{48}$ Por. tamże, 1,5 , SCh 175, 228-232, PSP 52, s. 20-21.

${ }^{49}$ Por. A. Żurek, Formacja intelektualno-ascetyczna duchowieństwa $w$ V-VI wieku w Galii na podstawie pism św. Cezarego z Arles, dz. cyt., s. 176-177.
} 


\section{ZAKOŃCZENIE}

Formacja do kapłaństwa od samego początku stanowiła ważny element w procesie przygotowawczym kandydatów. Zapoczątkowana przez samego Chrystusa w ramach wspólnoty Apostołów zebranych wokół Mistrza, przybierała $\mathrm{w}$ pierwszych wiekach chrześcijaństwa różne formy. Kandydaci przygotowywali się do kapłaństwa we wspólnotach klasztornych czy też we wspólnotach funkcjonujących pod bacznym okiem biskupa.

We wszystkich tych formach przygotowania do kapłaństwa ważna była formacja intelektualno-ascetyczna. Wymagane było odpowiednie wykształcenie, połączone ze znajomością Biblii, a także odpowiednia formacja ascetyczna. Świętość życia charakteryzująca się odpowiednim podejściem do dóbr materialnych i praktykowanie czystości były wskaźnikami przydatności kandydata do stanu kapłańskiego. Te wysiłki podejmowane w ramach formacji do kapłaństwa owocowały w pracy duszpasterskiej.

\section{PREPARATION FOR THE PRIESTHOOD IN THE FIRST CENTURIES OF CHRISTIANITY}

\section{Summary}

The first teacher was Jesus Christ. He prepared the apostles to preach the Gospel. Then prepare for the priesthood, took various forms. In the first centuries of Christianity, it was important ascetical and spiritual preparation for the priesthood. Appropriate knowledge and holy life - it was a program to prepare for the priesthood. Created a community where young people prepare for the priesthood.

Keywords:

the priesthood, formation, holiness, material goods, celibacy 